\title{
Review
}

\section{The olfactory bulb as an independent developmental domain}

\author{
L López-Mascaraque ${ }^{\star, 1,3}$ and $\mathrm{F}$ de Castro ${ }^{2,3}$ \\ 1 Instituto Cajal-C.S.I.C., Madrid, Spain \\ ${ }^{2}$ Hospital Ramón y Cajal, Madrid, Spain \\ ${ }^{3}$ Both authors contributed equally to this work \\ * Corresponding author: L López-Mascaraque, Instituto Cajal, CSIC, Avenida del \\ Doctor Arce 37, 28002 Madrid, Spain. Tel: 915854708; Fax: 915854754; \\ E-mail: mascaraque@cajal.csic.es
}

Received 13.2.02; revised 30.4.02; accepted 7.5.02

Edited by G Melino

\begin{abstract}
The olfactory system is a good model to study the mechanisms underlying guidance of growing axons to their appropriate targets. The formation of the olfactory bulb involves differentiation of several populations of cells and the initiation of the central projections, all under the temporal and spatial patterns of gene expression. Moreover, the nature of interactions between the olfactory epithelium, olfactory bulb and olfactory cortex at early developmental stages is currently of great interest. To explore these questions more fully, the present review aims to correlate recent data from different developmental studies, to gain insight into the mechanisms involved in the specification and development of the olfactory system. From our studies in the pax6 mutant mice $\left(\mathrm{Sey}^{\mathrm{Neu}} / \mathrm{Sey}^{\mathrm{Neu}}\right.$ ), it was concluded that the initial establishment of the olfactory bulb central projections is able to proceed independently of the olfactory sensory axons from the olfactory epithelium. The challenge that now remains is to consider the validity of the olfactory bulb as an independent development domain. In the course of evaluating these ideas, we will review the orchestra of molecular cues involved in the formation of the projection from the $\mathrm{OB}$ to the olfactory cortex.

Cell Death and Differentiation (2002) 9, 1279-1286. doi:10.1038/ sj.cdd. 4401076
\end{abstract}

Keywords: axonal guidance; neurogenesis; olfactory epithelium; mutants; development; piriform cortex

Abbreviations: $\mathrm{CP}$, cortical plate; $\mathrm{GE}$, ganglionic eminence; $\mathrm{LOT}$, lateral olfactory tract; $\mathrm{OB}$, olfactory bulb; OBLS, olfactory bulb like structure; OC, olfactory cortex; OE, olfactory epithelium; ON, olfactory nerve; OR, olfactory receptor; OSN, olfactory sensory neuron

\section{Introduction}

The effect that the arrival of afferent fibers to their appropriate targets has on CNS development has not yet been fully established. Does it awake the developmental program of the cells at the site being innervated or, does their arrival simply serve to refine the later steps of the developmental program? In order to address this question, much attention has been focused on the sophisticated development of the mammalian cerebral cortex where two different theories have been proposed to explain the mechanisms underlying its formation. In the 'protomap' model, cortical regions are patterned prior to the migration of the newborn neurons (intrinsic control), ${ }^{1}$ an event presumably specified by important molecular determinants. $^{2}$ In this model, the arrival of innervating axons would merely serve to modify and refine the protomap (an important facet of maintenance). In the second model, the 'protocortex' theory, the newborn cortical neurons are a homogeneous cell population, that later on in corticogenesis are patterned into the distinct areas by the specific cues supplied by axons growing in from the thalamus (extrinsic control). ${ }^{3}$

The fact that one or both of these hypotheses may also operate during the development of the olfactory system is currently of great interest. The nature of the interactions between the olfactory epithelium (OE), olfactory bulb (OB) and olfactory cortex at early developmental stages is currently providing us with much food for thought. ${ }^{4,5}$ In order to gain a better insight into the mechanisms involved in the specification and development of the olfactory system, this review aims to explore recent data from different developmental studies. Our studies in the pax-6 mutant mouse led us to conclude that the initial establishment of the $\mathrm{OB}$ central projections can proceed independently of the olfactory sensory axons from the OE. ${ }^{6}$ This raises the question as to whether we can consider the $O B$ as an independent developmental domain, which in turn would offer support to the protomap hypothesis. In the course of evaluating these ideas, we will review the orchestra of molecular cues involved in forming the projections from the $\mathrm{OB}$ to the olfactory cortex.

\section{A brief overview of the olfactory system}

The establishment of the basic circuitry in the mammalian olfactory system commences with the olfactory sensory neurons (OSN) in the OE, a structure that develops during embryogenesis from the olfactory placode. Axons from OSN project to the $\mathrm{OB}$, where they form synapses on the dendrites of mitral/tufted cells to form the OB glomeruli. ${ }^{7,8}$ Each of the approximately 5 million OSNs in a rodent nose expresses only one of the 1000-1300 different olfactory receptor genes. ${ }^{9,10}$ The OSNs that express the same odorant receptor gene are randomly distributed within the nasal cavity but their axons selectively project into only $1-4$ of the 2000 glomeruli in the OB (for a review, see Mombaerts). ${ }^{11}$ The primary axons of the projection neurons from the $\mathrm{OB}$, mitral/tufted cells, preferen- 
tially grow into a very narrow region of the ventro-lateral part of the telencephalon, adjacent to the pial surface. Here they form the lateral olfactory tract (LOT). ${ }^{7,12-17}$ The axons of the LOT, send off collateral branches that target areas in the olfactory cortex, anterior olfactory nucleus, piriform cortex, olfactory tubercle, entorhinal cortex, and several amygdaloid nuclei. ${ }^{14,15,18-20}$ Recent studies have indicated that a stereotypic map exists of OB afferents to the olfactory cortex. Inputs from OSNs that express the same odor receptor map to precise clusters of target neurons in the olfactory cortex. This arrangement may permit each unique odor receptor code to be integrated, both to generate diverse complex odor sensations and to subsequently transmit such information to other cortical areas. ${ }^{21}$ The final layering of the OB will depend on the arrival of tangential migrating cells from the subventricular zone, the prospective interneurons of the $\mathrm{OB}$ (reviewed by Goldman and Luskin). ${ }^{22}$

Given this brief introduction to the olfactory system, the two development schemes cited above would suggest very different developmental routes. While the protomap theory predicts a simultaneous and independent initial organization of $\mathrm{OE}, \mathrm{OB}$, and the olfactory cortex, the protocortex theory predicts that the development of the $\mathrm{OB}$ would be a secondary process, dependent upon the arrival of the OSN fibers from the OE. In this model, the subsequent arrival of the LOT fibers to the cortex would be necessary to induce differentiation at that level.

\section{Mutual influences between $O E$ and $O B$}

The influence of the $\mathrm{OE}$ in triggering $\mathrm{OB}$ development has been well established in amphibians ${ }^{23-25}$ (for a review, see, Brunjes and Fraizer). ${ }^{26}$ However, this relationship has not been so intensely studied in mammals, although it has been shown that the arrival of olfactory axons does appear to have a dramatic influence on cell kinetics and the rate of precursor differentiation in the OB-anlage. ${ }^{27}$ It has been also suggested that inductive interactions from the frontonasal-mesenchyme are essential for the morphogenesis of both the OE and the OB. ${ }^{5,28}$ However, such work has not been extended to the very early stages of the olfactory placode formation. ${ }^{5}$

At the early stages of development, an area of the rostral telencephalon of the mammalian brain is already specified as an OB primordium. ${ }^{16}$ The arrival of OSN axons induces the macroscopic evagination of the $\mathrm{OB}$ and its prenatal layering, but not the differentiation of the mitral cells themselves. ${ }^{29,30}$ In fact, the differentiation of mitral cells commences earlier. ${ }^{31}$ The OSNs start to express the olfactory marker protein at E16 in the rat (around E1414.5 in the mouse), well after the establishment of the first connections from the $\mathrm{OE}$ to the $\mathrm{OB} .^{32-35}$ However, the inductive role of the $O B$ in this type of maturation remains unclear. In the homozygous pax- 6 mutant, a deficient $O B$ (named OBLS, olfactory bulb like structure) starts to develop in the telencephalic vesicle in the total absence of an olfactory nerve. ${ }^{6}$ Mitral-like cells from the OBLS extend axons that form a bundle reminiscent of the LOT (see more details below). These observations suggest that the protomap hypothesis might be applicable to early developmental events in the olfactory system (i.e., mitral/ tufted cells neurogenesis in the OB primordium, and OSN neurogenesis in the $\mathrm{OP}$, with their respective efferent projections). However, if this were the case, multiple tissuetissue inductive interactions ${ }^{5}$ might also be important for events later in development (i.e., the macroscopical evagination and layer formation of the $\mathrm{OB}$ ). This suggestion is supported by the fact that neurogenesis is delayed in both the $\mathrm{OB}$ and $\mathrm{OE}$, it is initiated at $\mathrm{E} 10-10.5$ in the $\mathrm{OB}$ (mouse, mitral cells) and by E9.5 in the OE (mouse, OSNs) (mouse; ${ }^{6,35,36}$ rat; $^{29-32}$ see Figure 1). In the different areas of the olfactory cortex, neurogenesis occurs in an anteroposterior succession, starting well before the arrival of innervating $\mathrm{OB}$ axons ${ }^{18,37}$ (Figure 1). Recently, it has been suggested that supernumerary glomeruli in the OB do not stabilize because the number of afferent axons is too small to support stable glomerular formation. This event has been named the 'interdependence phenomenon' among OSN axons. ${ }^{38} \mathrm{~A}$ summary of the time scale of generation and axon extension in the rat and mouse for the three primary components of the olfactory system is shown in Figure 1. In mice, the first OSNs are generated by E9 and the first OSN axons differentiate by E9.5-10.5. These axons do not arrive in the telencephalic vesicle/OB primordium before E11, 0.5 days after the first mitral cells are generated (E10.5). The first mitral cell axons leave the $\mathrm{OB}$ at E11.5 and begin to innervate the olfactory cortex at E15, long after the initiation of neurogenesis in the piriform cortex (E9.5-11).

In accordance with the protocortex hypothesis, we could imagine that the $\mathrm{OE}$ and the $\mathrm{OB}$ develop independently? The protocortex hypothesis is based on sequential events, which correspond to a kind of hierarchy. Within this hierarchy, the OE should prevail over the OB, i.e.: the OE should dictate $O B$ development from the first moment, as has been suggested by some authors. ${ }^{26,27,39}$ However, none of these authors have proposed that a similar relationship might exist between the $\mathrm{OB}$ and the olfactory cortex, perhaps because of the well known studies regarding the triggering of neurogenesis in the cortex. ${ }^{18,31,37}$ Shouldn't these studies be discussed in the context of the development of the olfactory system or when arguing in favor of a sequential series of events between the $\mathrm{OE}$ and $\mathrm{OB}$ ? One of the strongest points in support of the protocortex hypothesis is the fact that mitral cell neurogenesis starts at $\mathrm{E} 11$ in the mouse $\mathrm{e}^{35}$ and has been estimated to commence at E14 in the rat. ${ }^{27}$ On the basis of the timescale represented in Figure 1, one would expect mitral cell neurogenesis to commence at E12.5 in the rat and not at E14. This implies that at the time that these authors consider that the first OSN axons are entering the telencephalic vesicle, neurogenesis has already started in the OB-anlage. Thus, the sequence of events (OE-OB) proposed by these authors is only maintained due to the differences in determining the embryonic ages. Exactly the same independence is observed in the olfactory cortex (Figure 1) where cortical neurons are generated well before the arrival of mitral cell axons.

Now, let us turn our attention to results from different experimental models in which the $\mathrm{OB}$ or the $\mathrm{OE}$ has been altered. Projection neurons of the $\mathrm{OB}$ strongly express the mammalian brachyury homologue gene Tbr1. In Tbr1 


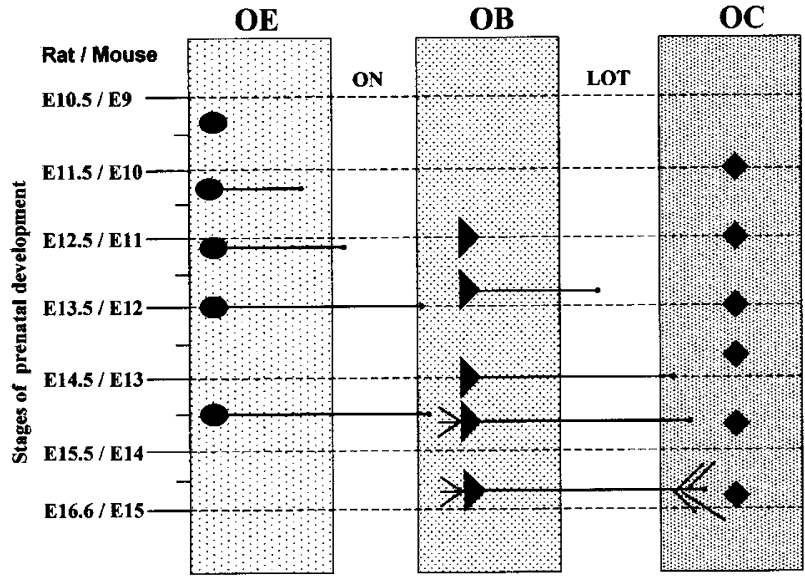

Figure 1 Schematic representation of neurogenesis and axonogenesis in the olfactory system. Neurogenesis of olfactory sensory neurons (OSN, ovals) has started by E9-9.5, of mitral cells (triangles) by E11 and in the olfactory cortex by $\mathrm{E} 10$ (rhombus). Axogenesis of the mitral cells (E11.5) is triggered before the arrival of the olfactory nerve $(\mathrm{ON})$ axons to the telencephalic surface (E12). Mitral cells display dendrites at the time that the first $\mathrm{ON}$ axons enter into the $\mathrm{OB}$ (E13.5). Lateral olfactory tract axons collateralize to invade their cortical targets by E14.5-15. Cell generation in the three compartments of the olfactory system start independently, presumably due to intrinsic control mechanisms (protomap hypothesis). Embryonic developmental stages correspond to mouse (see rat equivalent in the left of the scheme). In the figure we have summarized data from different authors (see below) on a rat/mouse scale in which the date of detection of the vaginal plug in the mother is E0. (Studies summarized in this scheme are from references: $6,16,27,29-37$ )

knockout mice, a few cells with a mitral cell phenotype survive, but they do not project to the olfactory cortex (see below). Nevertheless, despite the absence of their target (mitral cell dendrites), OSN axons converge normally in the OB forming glomerular-like spheres ${ }^{40}$ (Table 1). Similarly, parallel studies in mice that are null-mutants for the mammalian homeobox genes $D / x-1$ and -2 , have demonstrated the absence of interneurons ${ }^{40}$ (Table 1). Since in these mice axons converge to form glomerular spheres in the absence of OB interneurons it seems that neither do these cells contribute significantly to the targeting of OSN axons $^{40}$ (Table 1). Conversely, in mutations of the homeobox gene, Emx2 (but not the Emx1), the olfactory nerve fails to make contact with the OB. As a result, the mitral cell layer is disorganized, although an apparently normal LOT does form ${ }^{41}$ (Table 1). The data from these Tbr-1, DIx-1, $D / x-2$ and Emx2 mutants argue in favour of the establishment of a topographic map between the $\mathrm{OE}$ and presumptive $\mathrm{OB}$ independent of the projection neurons and the interneurons of the $\mathrm{OB}$, and the putative cues provided by them. However, the data from the Emx2 mutants does suggest that the OSN axons may help to ensure the orderly arrangement of mitral cells, although the functional significance of this is unclear. One singular case is the low affininity low growth factor receptor, p75NTR, which indirectly influences the growth of olfactory axons (in the early postnatal period there is an exuberant growth of some OSN axons), but the convergence into the $O B$ is normal, and they originated a transient abnormal lamination in the dorsocaudal OB. ${ }^{42}$
What happens after the genetic or surgical elimination of the OE? Odorant receptor gene expression by OSNs is completely independent of the $\mathrm{OB}$, either in the absence of an $\mathrm{OB}$ during embryogenesis ${ }^{43}$ or during regeneration after OSN lesion. ${ }^{44,45}$ Neither total nor partial sensory olfactory deprivation (closure of the nostril by electrocauterization) in newborns has any apparent effect on the number of OSNs in the $\mathrm{OE}^{46}$ (Table 1). Similarly, although olfactory deprivation results in a $25 \%$ size reduction of the $O B$, the cellular populations remain correctly laminated and their numbers appear to be normal ${ }^{46-51}$ (Table 1). However, Meisaimi and Safari ${ }^{52}$ reported a larger reduction in the number of tufted cells than of mitral cells following olfactory deprivation. Neither the number nor the size of the glomeruli were noticeably different after olfactory deprivation, although an increase in the ratio of mitral/granule cells was observed. ${ }^{46}$ Moreover, the pattern of reinnervation established by newly generated OSNs after global chemical deafferentation resembles the original topography. ${ }^{53}$ In summary, naris closure appears to have its major effects early postnatally, though such procedure would be difficult to carry out prenatally and therefore this has not been pursued in the embryo. ${ }^{26}$ In general, deprivation commenced in postnatal/adult animals, when all the connections between the $\mathrm{OE}$ and the $\mathrm{OB}$ have already been established. Nevertheless, similar changes have been observed when odor-evoked signaling was genetically eliminated, before connections are established, for example in mice lacking either functional olfactory cyclic nucleotidegated channels ${ }^{54}$ (Table 1 ), $\mathrm{G}_{(\mathrm{olf})}$, the major $\mathrm{G}$ protein $\alpha$ subunit in olfactory receptors ${ }^{55}$ or OMP, the olfactory marker protein, which takes part in odor perception ${ }^{56}$ (Table 1). Furthermore, some peripheral olfactory projections are affected in mice deficient for a cyclic nucleotidegated channel subunit, suggesting that the pathfinding of these axons is in part influenced by odorant-dependent activity. ${ }^{57}$ This is especially relevant for the mitral cells, whose only response to naris closure relates to the perikaryal size and the reciprocal synapses between mitral and granule cells, while the LOT cross-sectional area remains completely normal. ${ }^{46}$ No hypertrophic changes in non-deprived laminae of the OBs were observed, suggesting that no compensatory changes occur after olfactory deprivation. ${ }^{46}$

Interestingly, blocking odor transduction by either naris closure or by genetically engineering the loss of receptors or channels, does not affect the convergence of OSN axons in the $\mathrm{OB}^{54,55}$ (Table 1). Moreover, the restoration of the projection from the OE after genetic ablation suggests that the positional cues involved in the formation of the olfactory projection might persist in the OB throughout the entire life of the animal. ${ }^{58}$ Thus, a putative 'pioneer' mechanism for the rest of the olfactory fibers seems unlikely, although higher resolution studies are called for to address this specific issue. ${ }^{58,59}$ Together, this could explain the fact that continuously-generated OSNs establish the proper connections within the $\mathrm{OB}$ throughout the animals lifetime, and the map of olfactory projections remains stable, despite the continual renewal of the OSN population. 
Table 1 Results from different experimental models in which the olfactory bulb or the olfactory epithelium has been altered

\begin{tabular}{|c|c|c|c|c|c|c|c|}
\hline & Animal & OSN & ON & $\begin{array}{l}\text { Convergence } \\
\text { ON into OB }\end{array}$ & $\begin{array}{l}\text { Mitral/Tufted } \\
\text { cells }\end{array}$ & $\begin{array}{c}\text { OB } \\
\text { interneurons }\end{array}$ & LOT \\
\hline \multicolumn{8}{|l|}{ Axotomy and } \\
\hline OP ablation 24 & Xenopus embryos & $\varnothing$ & $\varnothing$ & $\varnothing$ & $\varnothing$ & $\varnothing$ & $\varnothing$ \\
\hline ON section partial ${ }^{24}$ & Xenopus embryos & L (50\%) & L (50\%) & $?$ & L (50\%) & $?$ & $?$ \\
\hline OB ablation ${ }^{44}$ & Adult rat & $\mathrm{N}$ & $\varnothing$ & $\dot{\varnothing}$ & $\mathrm{N}$ & $\dot{N}$ & $\dot{N}$ \\
\hline OB ablation ${ }^{45}$ & Juvenile catfish & $\stackrel{\mathrm{N}}{\text { (regenerate) }}$ & $\begin{array}{c}\varnothing \\
\text { (regenerate) }\end{array}$ & $\varnothing$ & $\varnothing$ & $\varnothing$ & $\varnothing$ \\
\hline \multicolumn{8}{|l|}{ Total/partial postnatal } \\
\hline Naris occlusion ${ }^{48}$ & Postnatal rat & - & - & - & $\stackrel{\mathrm{N}}{\text { (Small OB) }}$ & $\stackrel{\mathrm{N}}{(\text { Small OB) }}$ & $\mathrm{N}$ \\
\hline $\begin{array}{l}\text { Nostril closure by } \\
\text { electrocauterization }^{46}\end{array}$ & Neonatal mice & $\mathrm{N}$ & $\mathrm{N}$ & $\mathrm{N}$ & $\begin{array}{c}\mathrm{N} \\
\text { (Small OB) }\end{array}$ & $\mathrm{N}$ & $\mathrm{N}$ \\
\hline $\begin{array}{l}\text { Stimulus-deprived } \\
\text { Closure of one nostril }\end{array}$ & P25 rats & - & - & - & $\begin{array}{l}\mathrm{L}(40 \%) \\
\text { (Small OB) }\end{array}$ & $?$ & $?$ \\
\hline $\begin{array}{l}\text { Surgical closure of an } \\
\text { external naris } \\
50\end{array}$ & P1-P30 rats & - & - & - & $\begin{array}{c}\mathrm{N} \\
\text { (Small OB) }\end{array}$ & $\begin{array}{c}\text { I } \\
\text { (Small OB) }\end{array}$ & $\mathrm{N}$ \\
\hline Focal denervation ${ }^{49}$ & $\mathrm{P} 10$ and $\mathrm{P} 20$ rats & & & & $\mathrm{L}$ & & $\mathrm{N}$ \\
\hline $\begin{array}{l}\text { Chemical } \\
\text { deafferentation }\end{array}$ & $\begin{array}{l}\text { Adult } H-O M P-l a c Z-6 \\
\text { transgenic mice }\end{array}$ & $\stackrel{\mathrm{N}}{\text { (recovery) }}$ & $\stackrel{\mathrm{N}}{\text { (recovery) }}$ & $\begin{array}{c}\mathrm{N} \\
\text { (recovery) }\end{array}$ & $\mathrm{N}$ & $\mathrm{N}$ & $?$ \\
\hline \multicolumn{8}{|l|}{ Functional deprivation } \\
\hline$G_{O L F}-1-55$ & Neonatal mice & $\mathrm{N}^{*}$ & $\mathrm{~N}$ & $\mathrm{~N}$ & $\mathrm{~N}$ & ? & $?$ \\
\hline$O_{C N G}-$ channel $^{-/-54}$ & Mice & $\mathrm{N}^{*}$ & $\mathrm{~N}$ & $\mathrm{~N}$ & $\stackrel{\mathrm{N}}{\text { (Small OB) }}$ & $\mathrm{N}$ & $\mathrm{N}$ \\
\hline $\begin{array}{l}\text { Targeted mutagenesis } \\
\text { of the OCNC1 gene }\end{array}$ & $\begin{array}{l}\text { Mice with } \\
\text { unresponsive OSNs }\end{array}$ & $\mathrm{N}^{*}$ & $\mathrm{~N}$ & $\mathrm{~N}$ & $?$ & $?$ & $?$ \\
\hline \multicolumn{8}{|l|}{ Mutant animals } \\
\hline Pax $-6^{-1-6}$ & $\begin{array}{c}\text { Mouse Sey } \\
\text { embryos }\end{array}$ & $\varnothing$ & $\varnothing$ & $\varnothing$ & $\begin{array}{l}\text { Mitral like cells } \\
\text { in OBLS }\end{array}$ & Disorganized & $\begin{array}{l}\mathrm{N} \\
\mathrm{N}\end{array}$ \\
\hline$E M \times 2^{-/-41}$ & Mouse embryos & $\mathrm{N}$ ? & $\mathrm{N}$ ? & $\varnothing$ & Disorganized & $\mathrm{N}$ & $\mathrm{N}$ \\
\hline$X t^{J-1-6}$ & $\begin{array}{l}\text { Mouse embryos } \\
\text { (OB agenesis) }\end{array}$ & $\mathrm{N}$ & $\mathrm{N}$ & $\widetilde{\varnothing}$ & $\varnothing$ & $\varnothing$ & $\varnothing$ \\
\hline$T b r 1^{-/-40}$ & Mouse embryos & $\mathrm{N}$ & $\mathrm{N}$ & $\mathrm{N}$ & $\varnothing$ & Disorganized & $\varnothing$ \\
\hline$D / \times 1^{-/-}, D / \times 2^{-/-40}$ & Mouse embryos & $\mathrm{N}$ & $\mathrm{N}$ & $\mathrm{N}$ & $\widetilde{N}$ & $\varnothing$ & $?$ \\
\hline NCAM-180-/-34 & Mouse embryos & $\mathrm{N}$ & $\mathrm{N}$ & $\mathrm{N}$ & $\stackrel{\mathrm{N}}{(\text { Small OB) }}$ & $\stackrel{N}{N}$ & $\mathrm{~N}$ \\
\hline$O M P^{-/-56}$ & Postnatal mice & $\mathrm{N}$ & $\mathrm{N}$ & $\mathrm{N}$ & $\mathrm{N}$ & $\mathrm{N}$ & $?$ \\
\hline \multirow[t]{2}{*}{$p 75 N T R^{-1-42}$} & Embryos and & $\mathrm{N}$ & $\mathrm{N}$ & $\mathrm{N}$ & $\mathrm{N}$ & $\mathrm{N}$ & $\mathrm{N}$ \\
\hline & postnatal mice & & & & \multicolumn{3}{|c|}{ (OB protruded (OB protruded) } \\
\hline
\end{tabular}

$\mathrm{N}=$ Normal phenotype/structure; $\mathrm{N}^{\star}=$ Normal phenotype/structure but non responsive to odors; $\varnothing=$ Not formed/disappeared; I = Increased number of cells; $\mathrm{L}=\mathrm{L}$ ow number of cells; ? = not described. Abbreviations: LOT, lateral olfactory tract; OB, olfactory bulb; OBLS, olfactory bulb-like structure; ON, olfactory nerve; OSN, olfactory sensory neuron.

It has become widely accepted that different mutations for the pax- 6 gene, including the spontaneous mutation Small Eye ${ }^{60,61}$ produce different alterations. These alterations include the absence of eyes and of nasal structures such as the $\mathrm{OE}$ and the OB. Using a panel of region and field specific molecular markers, careful study of these animals revealed the presence of a prospective $O B$ in the rostrolateral part of the telencephalic vesicle, named the olfactory bulb-like structure ${ }^{6}$ (OBLS; Table 1). Our findings suggest that the pax- 6 mutation disturbs anatomical development, while early $\mathrm{OB}$ differentiation and the beginning of the central projections are not affected. To date, we have been unable to identify an olfactory nerve that enters the OBLS in these mutants, although in some cases we have observed immature structures suggesting that a remnant of the $\mathrm{OE}$ is present in the Small Eye mutants. $^{6}$ Unfortunately, the PCD mutant (spontaneous
Purkinje cell-deficient mouse), in which a complete loss of mitral cells has been demonstrated, does not provide a complementary model because mitral cell loss occurs postnatally (at 3-4 months, the tufted cells remaining normal). Moreover, the number of cells in the $O B$ is normal in the embryo and young adult PCD mice. ${ }^{62}$ However, the thickness of the LOT in the postnatal animals does become significantly reduced after the loss of mitral cells.

In summary, these studies demonstrate that OB cells can survive without the $\mathrm{OE}$ and can even begin to differentiate without the arrival of its primary afferent fibers. Furthermore, OSNs are able to survive and are capable of completing their continuous replacement and axonal regeneration even in the absence of $\mathrm{OB}$, although the rate of replacement may be affected. Nevertheless, both structures seem to be independent of one another for their respective survival. These observations do not preclude the 
conclusions drawn by some authors that the OSN axons influence later stages of $\mathrm{OB}$ development. ${ }^{16,23,27,34,51}$

\section{Molecular signals guiding the formation of the LOT}

If the formation of the distinct olfactory structures and axons initially progresses independently, identifying developmental cues that control these processes might shed light on some of the more controversial points reviewed here. It is possible that axons from the AOB projection neurons, located deep within the LOT, could serve as pioneer axons to subsequently guide OB axons. The timing of the formation of the LOT, and of the arrival of mitral cell axons to their final targets in the olfactory cortex supports this idea. ${ }^{15,16,31}$ However, in the absence of AOB axons, the OB mitral cells enter and form a LOT. ${ }^{36}$ This observation seems to rule out the notion that $A O B$ projection neurons provide pioneer axons and rather, suggests that intrinsic signals from the telencephalon are more likely to govern the formation of the LOT. ${ }^{6}$ Below, we shall analyze two of the candidate mechanisms.

1-Contact-mediated mechanisms Cell adhesion molecules are good candidates to act as contact mediated signals in the formation of the LOT, particularly molecules such as NCAM$\mathrm{H},{ }^{63} \mathrm{OCAM}^{64}$ and $\mathrm{Nr}-\mathrm{CAM}$. The latter molecules may act together or in combination with TAG-1/axonin- $1^{65}$ although to date, they have not been directly implicated in the formation of the LOT. Other important contact-molecules like reelin or the ephrins/Eph signaling system do not appear to participate in the formation/targeting of the LOT. ${ }^{66,67}$ The existence of guide-post cells for mitral/tufted cell axons has also been proposed. ${ }^{16}$ Such cells have been identified by the mAb lot1 as a subset of early-generated neurons formed exclusively in the neocortex, which migrate to reach their position in the basal telencephalon, thereby enclosing the LOT area. ${ }^{68,69}$ These lot1-positive cells may produce factors that either attract or support axonal outgrowth. Indeed, lot1-positive cells seem to form a border in most areas of the olfactory cortex, beyond which LOT axons do not grow. ${ }^{68}$ However, the addition of the mAB lot1 does not alter the formation of the LOT in organotypic cultures. ${ }^{68}$ Given the poor degree of heterogeneity expected in the LOT projection when compared to the olfactory nerve, it seems more likely that such contactmediated mechanisms contribute less to the formation of the LOT than in the case of the olfactory nerve. ${ }^{59,70}$

2-Secreted cues It seems highly probable that secreted cues are involved in the formation of the LOT. ${ }^{71}$ The first one to be identified, Slit-2, is putatively secreted by the septum and acts through its functional receptor Robo-1. ${ }^{72,73}$ However, Slit-2 may not play a simple role in this process. ${ }^{36,69}$ Recently, the group of Pini suggested that a concurrent cue may also exist that is responsible for the repellent activity of the septum and that which may be different from Slit-2 (see Figure 2). ${ }^{74}$ LOT axons also respond selectively to the secreted semaphorins. Sema 3F repels LOT axons, preventing them from invading the cortical plate and the ganglionic eminence, while Sema 3B attracts LOT axons, forcing them to remain at the surface of the telencephalon (see Figure 2). ${ }^{17}$ Meanwhile, other secreted semaphorins, e.g. Sema 3A, do not appear to

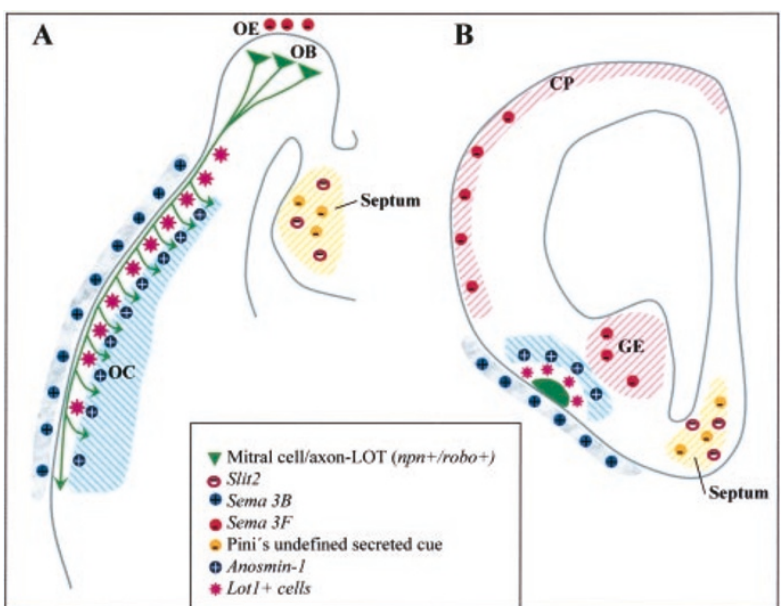

Figure 2 Cues guiding axonal outgrowth from projection neurons of the olfactory bulb. Horizontal (A) and coronal (B) sections of the head showing olfactory structures and annexes. Mitral cells and their axons (LOT) are represented in green. Different chemorepellents prevent LOT axons from entering different structures (septum, ganglionic eminence, cortical plate) and force them to occupy a position at the surface of the telencephalic vesicle. This is reinforced by lot $1^{+}$-cells (violet stars) and two chemoattractants, Sema 3B (secreted by progenitors of the skull bones) and anosmin-1 (produced by the olfactory cortex). The latter is critical for the formation of collaterals from the LOT axons (green arrows in A) that will invade their targets (see text for details). Abbreviations: CP: cortical plate; GE: ganglionic eminence; OB: olfactory bulb; OC: olfactory epithelium; OE: olfactory epithelium

influence the outgrowth of $\mathrm{OB}$ axons. ${ }^{17,72}$ Interestingly, within the $\mathrm{OB}$, some cells and their axons express Neuropilin-1 and $2,6,36,75$ functional receptors of the semaphorin family. However, the only two knockout mice so far analyzed, carrying a null mutation for the secreted Sema $3 \mathrm{~A}$ and for its receptor Neuropilin-1, do not show major alterations in the developing LOT. $^{76}$ Functional receptors for secreted molecules of the Netrin family, such as DCC or Unc5H3 are strongly expressed by developing mitral cells of the OB. ${ }^{77,78}$ However, neither secreted Netrin-1 nor a secreted form of the Netrin-G1 (anchored to plasmalemma membrane) exert any effect on $\mathrm{OB}$ axonal outgrowth. ${ }^{17,72,79}$

It has been suggested that a stereotypic map of mitral cell termination in the olfactory cortex might be established by odor receptors providing an input to those mitral cells. ${ }^{21}$ Thus, the OSNs expressing the odor receptor 17 terminate on mitral cells that innervate the 17 glomerulus and, in turn, the axons from those mitral cells would sort to form synaptic clusters in piriform cortex. Axonal collaterals bud from the primary axons of the LOT. This phenomenon is a widespread strategy used by growing axons to invade target areas in the developing nervous system, ${ }^{80}$ and the only way for mitral and tufted cells from the OB to invade olfactory target areas in the cortex in vivo. ${ }^{81}$ It is widely accepted that the same cues involved in guiding axonal pathfinding should be the ones responsible for axonal collateralization. One example is that of Slit-2, a well-known chemorepellent for axonal guidance that seems to be a positive regulator of sensory axonal branching. ${ }^{69,82}$ On the other hand, other studies suggest that different cues may 
be used to induce collateral axon branching than for axonal pathfinding. ${ }^{81}$ The lot1-positive cells, which do not seem to be involved in the collateral branching of the OB mitral cells could provide an example of this phenomenon. ${ }^{68}$ Anosmin1, a protein defective in Kallmann syndrome (syndrome: anosmia plus hypogonadotropic hypogonadism) seems to be directly involved in the formation of mitral cell axon collaterals during the developmental period in which the olfactory cortex is colonized by LOT collaterals. ${ }^{83}$ After a protracted period of waiting, possible to facilitate neutralization or overriding of inhibitors of collateral sprouting as suggested by Fujisawa's group, ${ }^{68}$ Anosmin- 1 enhances axonal sprouting but does not affect the growth of primary $\mathrm{OB}$ axons. At earlier developmental stages (rat E15), Anosmin-1 seems to contribute to the guidance of primary $\mathrm{OB}$ axons, but it does not trigger sprouting. ${ }^{83}$ In contrast, expression patterns do not suggest a role for slit molecules in the collateralization of LOT axons that invade olfactory cortex. 84

Taken together, it would appear that the cues which guide OB axonal outgrowth act in a cooperative way that includes both attractive and repulsive signals, perhaps in a hierarchy as suggested elsewhere. ${ }^{85}$ It is noteworthy that some of the cues which do not seem to be useful for guiding $\mathrm{OB}$ mitral cell axons (e.g. Sema 3A, Netrin-1), do appear to be important for the growth of OSN axons. ${ }^{86,87}$ Therefore, the possible roles played by molecules in the development of the olfactory pathway may be diverse and indeed, the possibility still exists that cues that attract OSN axons but repel mitral cell axons might remain to be identified. Finally, we must also remember that the interaction of secreted molecules with non-diffusible components of the extracellular matrix may have important functional implications for the establishment of the proper synaptic connectivity during development. ${ }^{36,83}$

As has been recently described, it seems that the cues that guide OSN axons to form proper synapses within the OB are preserved throughout the life of the animal. ${ }^{58,59}$ It is also remarkable that the cues involved in the formation of the LOT are present and expressed in the correct structures in the Small Eye mutant mouse. ${ }^{6}$ This might explain how a LOTlike projection forms in these mutants from the ectopic and malformed OBLS. ${ }^{6}$ Both these studies emphasize the idea of an independent $\mathrm{OB}$ and therefore, support the existence of a protomap during the initial development of the olfactory system. However, we must not forget that, among all the signals that we have reviewed, both for the neurogenesis of mitral cells in the $\mathrm{OB}$ and for the initiation of the LOT formation, Tbr-1 may play a critical role. ${ }^{40}$ (Table 1 ).

\section{Conclusions}

From the data discussed above, we conclude that the protomap hypothesis provides a more plausible format than the protocortex theory for the development of the olfactory pathway. Indeed, relatively little data seems to support the protocortex model for the initial developmental events. The $\mathrm{OB}$ organizes independently of afferent projections from OSNs or other external influences. At later stages, signals provided by OSN inputs, and eventually other tissue-derived cues, will contribute to confer the mature appearance of $O B$, as recognized in adults. In the same sense, our studies of the mouse mutant pax-6, strongly suggest that the initial establishment of the central OB projections proceeds independently of the OSN axons that are arriving from the olfactory epithelium. This work opened up the possibility of identifying the intrinsic molecular guidance cues that are required for the patterning of the olfactory system. Thus, although it still remains poorly studied, we hypothesize that the independent development of the olfactory cortex follows the predicted protomap hypothesis. Indeed, studies performed elsewhere in the brain strongly support the idea that a protomap governs the development of the piriform cortices. For example, in the $G b x-2$ null-mutant mice, thalamic differentiation is disrupted and thalamic axons do not innervate the cortex. However, the patterns of several region-specific markers in the cortex develop normally, suggesting that factors intrinsic to the neocortex are responsible for the development of the cortex, or, at least, for the expression of these markers. ${ }^{88,89}$ Furthermore, if the strong morphogenetic agent FGF8 is ectopically expressed in the posterior telencephalon before the arrival of thalamic axons, the somatosensory cortex is partially duplicated, and an additional population of thalamic axons develops to innervate these extra barrels. ${ }^{2}$

Factors extrinsic to the developing cortex (the arrival of thalamo-cortical fibers) have also been shown to control the specification of the different cortical areas. ${ }^{90}$ An extension to the protomap hypothesis leads us to consider the regional expression in other telencephalic structures in the absence of a patterned afferent input. In this context, it has been generally accepted that the development and differentiation of the olfactory bulb depends on the arrival of olfactory sensory axons. Homozygous small eye mutant mice lack nasal structures including the olfactory epithelium and, an emergent olfactory bulb. Therefore, the initial development of the OB is not dependent of the OSN input

These studies suggest that a more profound analysis of protomap formation in the different structures that compose the olfactory cortex would be extremely interesting. It will be particularly important, to determine the molecular basis that governs the differentiation of the olfactory cortex into the LOT specific synaptic clusters as recently identified by Buck's group. ${ }^{21}$ It would also be useful to be able to analyze the relevance of the arrival of sensory afferents in refining the development of the OB. Finally, a model with an OB but lacking the LOT could be also determinant in clarifying the true influence that this projection has on the development of cortical structures.

\section{Acknowledgements}

We thank Drs De Carlos, Ferrús, Greer, Nieto and Valverde for critically reading this manuscript and Mark Sefton for editorial assistance. In addition, we thank Conchi García for helpful comments on the manuscript. Grant sponsors: Ministerio de Educación y Cultura (MEC) of Spain: PB96-0813, Consejería de Educación y Cultura de la Comunidad de Madrid: 08.5/0037/1998 (L López-Mascaraque) and Fondo de Investigaciones Sanitarias (FIS): 01/3136 and 00/3110 (F de Castro). 


\section{References}

1. Rakic $P$ (1988) Specification of cerebral cortical areas. Science 241: $170-176$

2. Fukuchi-Shimogori T and Grove EA (2001) Neocortex patterning by the secreted signaling molecule FGF8. Science 294: 1071-1074

3. O'Leary DD (1989) Do cortical areas emerge from a protocortex? Trends Neurosci. 12: $400-406$

4. Jefferis GS, Marin EC, Stocker RF and Luo L (2001) Target neuron prespecification in the olfactory map of Drosophila. Nature 414: 204-208

5. Wang X, Gao C and Norgren Jr RB (2001) Cellular interactions in the development of the olfactory system: an ablation and homotypic transplantation analysis. J. Neurobiol. 49: 29-39

6. Jiménez D, García C, de Castro F, Chédotal A, Sotelo C, De Carlos JA, Valverde $F$ and López-Mascaraque L (2000) Evidence for intrinsic development of olfactory structures in Pax-6 mutant mice. J. Comp. Neurol. 428: 511-526

7. Cajal SR (1890) Origen y terminación de las fibras nerviosas olfatorias. Gac. San. Barcelona (October)

8. Greer CA (1991) Structural organization of the olfactory system. In: Smell and Taste in Health and Disease, Getchell TV, Doty RL, Bartoshuk LM and Snow Jr JB, eds (New York: Raven) pp. 65-81

9. Malnic B, Hirono J, Sato T and Buck LB (1999) Combinatorial receptor codes for odors. Cell 96: 713-723

10. Zhang $X$ and Firestein $S$ (2002) The olfactory receptor gene superfamily of the mouse. Nat. Neurosci. 5: 124-133

11. Mombaerts P, Wang F, Dulac C, Chao SK, Nemes A, Mendelsohn M, Edmondson J and Axel R (1996) Visualizing an olfactory sensory map. Cell 87: $675-686$

12. Valverde F (1965) Studies on the Piriform Lobe (Harvard University Press)

13. Price JL (1973) A study of complementary laminar patterns of termination of afferent fibers to the olfactory cortex. J. Comp. Neurol. 150: 87-108

14. Devor M (1976) Fiber trajectories of olfactory bulb efferents in the hamster. J. Comp. Neurol. 166: $31-48$

15. Schwob JE and Price JL (1984) The development of axonal connections in the central olfactory system of rats. J. Comp. Neurol. 223: 177-202

16. López-Mascaraque L, De Carlos JA and Valverde F (1996) Early onset of the rat olfactory bulb projections. Neuroscience 70: $255-266$

17. De Castro F, Hu L, Drabkin H, Sotelo C and Chédotal A (1999) Chemoattraction and chemorepulsion of olfactory bulb axons by different secreted semaphorins J. Neurosci. 19: 4428-4436

18. Derer P, Caviness Jr VS and Sidman RL (1977) Early cortical histogenesis in the primary olfactory cortex of the mouse. Brain Res. 123: 27-40

19. Luskin MB and Price $J L$ (1982) The distribution of axon collaterals from the olfactory bulb and the nucleus of the horizontal limb of the diagonal band to the olfactory cortex demonstrated by double retrograde labeling techniques. J. Comp. Neurol. 209: 249-263

20. Scott JW, McBride RL and Schneider SP (1980) The organization of projections from the olfactory bulb to the piriform cortex and olfactory tubercle in the rat. J. Comp. Neurol. 194: 519-534

21. Zou Z, Horowitz LF, Montmayeur JP, Snapper S and Buck LB (2001) Genetic tracing reveals a stereotyped sensory map in the olfactory cortex. Nature 414 : $173-179$

22. Goldman SA and Luskin MB (1998) Strategies utilized by migrating neurons of the postnatal vertebrate forebrain. Trends Neurosci. 21: 107-114

23. Stout RP and Graziadei PP (1980) Influence of the olfactory placode on the development of the brain in Xenopus laevis (Daudin). I. Axonal growth and connections of the transplanted olfactory placode. Neuroscience 5:2175-2186

24. Byrd CA and Burd GD (1993) The quantitative relationship between olfactory axons and mitral/tufted cells in developing Xenopus with partially deafferented olfactory bulbs. J. Neurobiol. 24: 1229-1242

25. Graziadei PPC and Monti-Graziadei GA (1992) The influence of the olfactory placode on the development of the telencephalon in Xenopus laevis. Neuroscience 46: 617-629

26. Brunjes and Frazier (1986) Maturation and plasticity in the olfactory system of vertebrates. Brain Res. 396: 1-45

27. Gong $Q$ and Shipley MT (1995) Evidence that pioneer olfactory axons regulate telencephalon cell cycle kinetics to induce the formation of the olfactory bulb. Neuron 14: $91-101$
28. LaMantia A-S, Bhasin N, Rodees K and Heemskerk J (2000) Mesenchymal/ epithelial induction mediates olfactory pathway formation. Neuron 28: 411-425

29. De Carlos JA, López-Mascaraque L and Valverde F (1995) The telencephalic vesicles are innervated by olfactory placode-derived cells: a possible mechanism to induce neocortical development. Neuroscience 68: 1167-1178

30. De Carlos JA, López-Mascaraque L and Valverde F (1996) Early olfactory fiber projection and cell migration into the rat telencephalon. Int. J. Develop. Neurosci. 14: $853-866$

31. Bayer SA (1983) 3H-thymidine-radiographic studies of neurogenesis in the rat olfactory bulb. Exp. Brain Res. 50: 329-340

32. Roskams AJ, Cai X and Ronnett GV (1998) Expression of neuron-specific betaIII tubulin during olfactory neurogenesis in the embryonic and adult rat. Neuroscience 83: 191-200

33. Bailey MS, Puche AC and Shipley MT (1999) Development of the olfactory bulb: evidence for glia-neuron interactions in glomerular formation. J. Comp. Neurol. 415: $423-448$

34. TreloarH, Tomasiewicz H, Magnuson T and Key B(1997) The central pathway of primary olfactory axons is abnormal in mice lacking the N-CAM-180 isoform. $J$ Neurobiol. 32: 643-658

35. Hinds JW (1968) Autoradiographic study of histogenesis in the mouse olfactory bulb. I. Time of origin of neurons and neuroglia. J. Comp. Neurol. 134: 287-304

36. Sugisaki N, Hirata T, Naruse I, Kawakami A, Kitsukawa T and Fujisawa H (1996). Positional cues that are strictly localized in the telencephalon induce preferential growth of mitral cell axons. J. Neurobiol. 29: 127-137

37. Valverde F and Santacana M (1994) Development and early postnatal maturation of the primary olfactory cortex. Brain Res. Dev. Brain Res. 80: $96-$ 114

38. Ebrahimi FA and Chess A (2000) Olfactory neurons are interdependent in maintaining axonal projections. Curr. Biol. 10: 219-222

39. Humphrey T (1966) Correlations between the development of the hippocampal formation and the differentiation of the olfactory bulbs. Ala. J. Med. Sci. 3: 235269

40. Bulfone A, Wang F, Hevner R, Anderson S, Cutforth T, Chen S, Meneses J, Pedersen R, Axel R and Rubenstein JL (1998) An olfactory sensory map develops in the absence of normal projection neurons or GABAergic interneurons. Neuron 21: 1273-1282

41. Yoshida M, Suda Y,. Matsuo I, Miyamoto N, Takeda N, Kuatani S and Aizawa S (1997) Emx1 and Emx2 functions in development of dorsal telencephalon. Development 124: 101-111

42. Tisay KT, Bartlett PF and Key B (2000) Primary olfactory axons form ectopic glomeruli in mice lacking p75NTR. J. Comp. Neurol. 428: 656-670

43. Sullivan SL, Bohm S, Ressler KJ, Horowitz LF and Buck LB (1995) Targetindependent pattern specification in the olfactory epithelium. Neuron 15: 779 789

44. Konzelmann S, Saucier D, Strotmann J, Breer H and Astic L (1998) Decline and recovery of olfactory receptor expression following unilateral bulbectomy. Cell Tissue Res. 294: $421-430$

45. Fan J and Ngai J (2001) Onset of odorant receptor gene expression during olfactory sensory neuron regeneration. Dev. Biol. 229: 119-127

46. Benson TE, Ryugo DKand Hinds JW (1984) Effects of sensory deprivation on the developing mouse olfactory system: a light and electron microscopic morphometric analysis. J. Neurosci. 4: 638-653

47. Meisami $E$ (1976) Effects of olfactory deprivation on postnatal growth of the rat olfactory bulb utilizing a new method for production of neonatal unilateral anosmia. Brain Res. 107: 437-444

48. Brunjes PC (1994) Unilateral naris closure and olfactory system development Brain Res. Rev. 19: 146-160

49. Couper Leo JM, Devine AH and Brunjes PC (2000) Focal denervation alters cellular phenotypes and survival in the developing rat olfactory bulb. J. Comp. Neurol. 417: 325-336

50. Frazier LL and Brunjes PC (1988) Unilateral odor deprivation: early postnatal changes in olfactory bulb cell density and number. J. Comp. Neurol. 269: 355370

51. Matsutani S and Yamamoto N (2000) Differentiation of mitral cell dendrites in the developing main olfactory bulbs of normal and naris-occluded rats. J. Comp Neurol. 418: 402-410 
52. Meisami E and Safari L (1981) A quantitative study of the effects of early unilateral olfactory deprivation on the number and distribution of mitral and tufted cells and of glomeruli in the rat olfactory bulb. Brain Res. 221: 81-107

53. Cummings DM, Emge DK, Small SL and Margolis FL (2000) Pattern of olfactory bulb innervation returns after recovery from reversible peripheral deafferentation. J. Comp. Neurol. 421: 362-373

54. Lin DM, Wang F, Lowe G, Gold GH, Axel R, Ngai J and BrunetL (2000) Formation of precise connections in the olfactory bulb occurs in the absence of odorantevoked neuronal activity. Neuron 26: 69-80

55. Belluscio L, Gold GH, Nemes A and Axel R (1998) Mice deficient in G(olf) are anosmic. Neuron 20: 69-81

56. Buiakova OI, Baker H, Scott JW, Farbman A, Kream R, Grillo M, Franzen L, Richman M, Davis LS, Abbondanzo S, Stewart CL and Margolis FL (1996) Olfactory Marker Protein (OMP) Gene Deletion Causes Altered Physiological Activity of Olfactory Sensory Neurons. Proc. Natl. Acad. Sci. USA 93: 9858 9863.

57. Zheng C, Feinstein P, Bozza T, Rodriguez I and Mombaerts P (2000) Periphera olfactory projections are differentially affected in mice deficient in a cyclic nucleotide-gated channel subunit. Neuron 26: 81-91

58. Gogos JA, Osborne J, Nemes A, Mendelsohn M and Axel R (2000) Genetic ablation and restoration of the olfactory topographic map. Cell 103: 609-620

59. Potter SM, Zheng C, Koos DS, Feinstein P, Fraser SE and Mombaerts P (2001) Structure and emergence of specific olfactory glomeruli in the mouse. $\mathrm{J}$. Neurosci. 21: $9713-9723$

60. Hogan BL, Horsburgh G, Cohen J, Hetherington CM, Fisher G and Lyon MF (1986) Small eyes (Sey) a homozygous lethal mutation on chromosome 2 which affects the differentiation of both lens and nasal placodes in the mouse. J. Embryol. Exp. Morphol. 97: 95-110

61. Stoykova A, Fritsch R, Walther C and Gruss P (1996) Forebrain patterning defects in Small eye mutant mice. Development 122: 3453-3465

62. Bartolomei JC and Greer CA (1998) The organization of piriform cortex and the lateral olfactory tract following the loss of mitral cells in PCD mice. Exp. Neurol. 154: $537-550$

63. Seki T and Arai Y (1991) Expression of highly polysialylated NCAM in the neocortex and piriform cortex of the developing and the adult rat. Anat. Embryol. (Berl) 184: 395-401

64. Von Campenhausen H, Yoshihara $Y$ and Mori K (1997) OCAM reveals segregated mitral/tufted cell pathways in developing accessory olfactory bulb. Neuroreport 8: 2607-2612

65. Stoeckli ET and Landmesser LT (1995) Axonin-1 Nr-CAM and Ng-CAM play different roles in the in vivo guidance of chick commissural neurons. Neuron 14: 1165-1179

66. Caviness Jr VS and Sidman RL (1972) Olfactory structures of the forebrain in the reeler mutant mouse. J. Comp. Neurol. 145: 85-104

67. St John JA and Key B (2001) Chemically and morphologically identifiable glomeruli in the rat olfactory bulb. J. Comp. Neurol. 436: 497-507

68. Sato Y, Hirata T, Ogawa M and Fujisawa H (1998) Requirement for earlygenerated neurons recognized by monoclonal antibody lot 1 in the formation of lateral olfactory tract. J. Neurosci. 18: 7800-7810

69. Hirata T, Fujisawa H, Wu JY and Rao Y (2001) Short-Range Guidance of Olfactory Bulb Axons Is Independent of Repulsive Factor Slit. J. Neurosci. 21 2373-2379

70. Treloar HB, Feinstein P, Mombaerts P and Greer CA (2002) Specificity of glomerular targeting by olfactory sensory axons. J. Neurosci. 22: 2469-2477

71. Pini A (1993) Chemorepulsion of axons in the developing mammalian centra nervous system. Science 261: $95-98$

72. Li HS, Chen JH, Wu W, Fagaly T, Zhou L, Yuan W, Dupuis S, Jiang ZH, Nash W, Gick C, Ornitz DM, Wu JY and Rao Y (1999) Vertebrate slit a secreted ligand for the transmembrane protein roundabout is a repellent for olfactory bulb axons. Cell 96: $807-818$
73. Nguyen Ba-Charvet KT, Brose K, Marillat V, Kidd T, Goodman CS, TessierLavigne M, Sotelo C and Chédotal A (1999) Slit2-mediated chemorepulsion and collapse of developing forebrain axons. Neuron 22: 1-20

74. Patel K, Nash JA, Itoh A, Liu Z, Sundaresan V and Pini A (2001) Slit proteins are not dominant chemorepellents for olfactory tract and spinal motor axons. Development 128: $5031-5037$

75. Kawakami A, Kitsukawa T, Takagi S and Fujisawa H (1996) Developmentally regulated expression of a cell surface protein neuropilin in the mouse nervous system. J. Neurobiol. 29: 1-17

76. Kitsukawa T, Shimizu M, Sanbo M, Hirata T, Taniguchi M, Bekku Y, Yagi T and Fujisawa H (1997) Neuropilin-semaphorin III/D-mediated chemorepulsive signals play a crucial role in peripheral nerve projection in mice. Neuron 19: 995-1005

77. Przyborski SA, Knowles BA and Ackerman SL (1998) Embryonic phenotype of Unc5h3 mutant mice suggests chemorepulsion during the formation of the rostral cerebellar boundary. Development 125: 41-50

78. Shu T, Valentino KM, Seaman C, Cooper HM and Richards LJ (2000) Expression of the netrin-1 receptor deleted in colorectal cancer (DCC) is largely confined to projecting neurons in the developing forebrain. J. Comp. Neurol. 416: 201-212

79. Nakashiba T, Ikeda T, Nishimura S, Tashiro K, Honjo T, Culotti JG and Itohara S (2000) Netrin-G1: a novel glycosyl phosphatidylinositol-linked mammalian netrin that is functionally divergent from classical netrins. J. Neurosci. 20: 6540-6550

80. Kalil K, Szebenyi G and Dent EW (2000) Common mechanisms underlying growth cone guidance and axon branching. J. Neurobiol. 44: 145-158

81. Hirata T and Fujisawa H(1999) Environmental control of collateral branching and target invasion of mitral cell axons during development. J. Neurobiol. 38: 93-104

82. Wang KH, Brose K, Arnott D, Kidd T, Goodman CS, Henzel W and TessierLavigne M (1999) Biochemical purification of a mammalian slit protein as a positive regulator of sensory axon elongation and branching. Cell 96: 771-784

83. Soussi-Yanicostas N, de Castro F, Julliard K, Perfettini I, Chédotal A and Petit C (2002) Anosmin-1 defective in the X-linked form of Kallmann syndrome promotes axonal branch formation from olfactory bulb output neurons. Cell 109:217-228

84. Marillat V, Cases O, Nguyen Ba-Charvet KT, Tessier-Lavigne M, Sotelo C and Chedotal A (2002) Spatiotemporal expression patterns of slit and robo genes in the rat brain. J. Comp. Neurol. 442: $130-155$

85. Stein E and Tessier-Lavigne M (2001) Hierarchical organization of guidance receptors: silencing of netrin attraction by slit through Robo/DCC receptor complex. Science 291: 1928-1938

86. Renzi MJ, Wexler TL and Raper JA (2000) Olfactory sensory axons expressing a dominant-negative semaphorin receptor enter the CNS early and overshoot their target. Neuron 28: $437-447$

87. Williams-Hogarth LC, Puche AC, Torrey C, Cai X, Song I, Kolodkin AL, Shipley MT and Ronnett GV (2000) Expression of semaphorins in developing and regenerating olfactory epithelium. J. Comp. Neurol. 423: 565-578

88. Donoghue MJ and Rakic P (1999) Molecular evidence for the early specification of presumptive functional domains in the embryonic primate cerebral cortex. J. Neurosci. 19: 5967-5979

89. Miyashita-Lin EM, Hevner R, Wassarman KM, Martinez S and Rubenstein JL (1999) Early neocortical regionalization in the absence of thalamic innervation. Science 285: $906-909$

90. Schlaggar BL and O'Leary DD (1991) Potential of visual cortex to develop an array of functional units unique to somatosensory cortex. Science 252: $1556-$ 1560 